\title{
Determinants of the Islamic Stock Markets Integration
}

\author{
Bakri Abdul Karim ${ }^{1}$, Jyiona Fam Jxiaw Linn ${ }^{1} \&$ Zulkefly Abdul Karim² \\ ${ }^{1}$ Faculty of Economics and Business, Universiti Malaysia Sarawak (UNIMAS), Malaysia \\ ${ }^{2}$ Faculty of Economics and Management, Universiti Kebangsaan Malaysia (UKM), Malaysia \\ Correspondence: Bakri Abdul Karim, Universiti Malaysia Sarawak (UNIMAS)
}

Received: July 18, 2017

Accepted: August 17, 2017

Online Published: August 21, 2017

doi:10.5430/afr.v6n3p147

URL: https://doi.org/10.5430/afr.v6n3p147

\begin{abstract}
This study examines the macroeconomic determinants of Islamic stock markets integration among 10 selected Islamic stock markets. Both pooled OLS and panel data regressions are used in this study over the period spanning from 2010 to 2014. Some of Islamic stock markets are less integrated thus there is opportunity to gain from international portfolio diversification. However, there are some Islamic stock markets are strongly integrated. The results from the Pooled OLS show that all variables are insignificant explaining the Islamic stock markets integration. From the panel estimation, the study revealed that only GDP growth differential and inflation differential are significant influencing the Islamic stock markets integration. The higher dispersion of GDP and inflation rate the more integrated the Islamic stock markets. The results of this study have significant implications on international investors (potential risks and returns of international diversification) and on policy makers (formulation of financial policies and financial liberalization).
\end{abstract}

Keywords: Islamic Stock Markets Integration, Macroeconomics, Portfolio Diversification

\section{Introduction}

There have been voluminous studies investigating the stock markets integration in both developed and developing markets worldwide as it has implication on both international portfolio diversification and financial stability of a country. When several stock markets move together and have high correlations, this indicates fewer benefits from portfolio diversification across the markets. The financial markets become more integrated due to the financial globalization, removal of investment barriers, financial innovation and technological advancement (Karim and Hoe, 2012). Francis et al. (2002) and Yang et al. (2003) argued that the financial markets have become more integrated after the Asian financial crisis. On the other hand, Abdul Majid and Kassim (2009) find that the stock markets have shown greater degree of integration during the US subprime crisis. Interestingly, Karim et al. (2010) provide evidence that the Islamic stock markets are not integrated in both pre- and during subprime crisis thus offer a potential benefits for portfolio diversification.

Islamic finance industry has developed across the globe in the past decades and has shown fast growth at 10-15\% annual rates across all sectors of the Islamic financial service industry. According to the Malaysia International Islamic Financial Centre (MIFC), the total assets of the Islamic finance industry is predicted to surpass USD2.4 trillion in 2015 and continue to growth to exceed USD 4 trillion by 2020. In addition, Islamic equity markets are also a very noteworthy segment in Islamic finance. Investors worldwide have attracted to diversify their investment in these shariah-compliance equities. Based on Dow Jones Islamic Market World Index, in terms of market capitalization as of end of August 2016, Islamic stock markets was valued at more than USD19 trillion. The Islamic stock markets are believed to be relatively more stable as compared to the conventional stock markets as they are free from Riba (interest, and usury) and maysir (gambling), speculative activities and gharar (uncertainty) which are extremely prohibited in Islam.

Early studies on stock market integration can be traced in Grubel (1968) and Levy and Sarnat (1970). Grubel (1968) has provided evidence of lower correlations among national stock markets thus implies international portfolio diversification benefits. However, many current studies have shown increasing dynamics linkages among the stock markets worldwide. According to Kearney and Lucey (2004), the global economic and financial systems are more integrated due to the rapid growth of global trade in goods, services and financial assets. In addition, Chowdhury (2005) noted that the expansion of intra-regional trade is one of the efficient ways of markets integration. Therefore, 
stronger the bilateral trade relationship between two countries, the higher degree of integration (Pretorius, 2002; Karim and Majid, 2010).

Although there are huge volumes of studies examining the issue of stock market integration in both developed and developing markets, studies on the Islamic stock markets integration worldwide are still limited. There are two different findings have been documented in terms of Islamic stock markets integration. The first group has provided evidence that the Islamic stock markets are not integrated thus provides opportunity for portfolio diversification. For example, Marashdeh (2005) provides evidence that there is no integration between the selected Middle-East and North African (MENA) stock markets and the developed markets of the US, the UK and Germany. For the case of the stock markets of Bahrain, Kuwait, Oman, Qatar, Saudi Arabia and United Arab Emirates, Bley and Chen (2006) document evidence that these markets provide potential benefits of international portfolio diversification. In addition, Karim et al. (2010) provide evidence of potential diversification in Islamic stock markets worldwide even during the US subprime crisis. In a more recent study, Hussin et al. (2013) found that there is no integration between Islamic stock markets of Malaysia, Indonesia and the World Islamic market.

The second group has provided evidence of the existence of Islamic stock markets integration. For instance, Darrat et al. (2000) find that the stock markets of Egypt, Morocco and Jordan are integrated among themselves as well as with the major developed markets. Abdul Majid et al. (2007) explore the degree of integration among eight Islamic countries' stock markets (Turkey, Egypt, Oman, Kuwait, Malaysia, Indonesia, Bangladesh and Pakistan) and the developed markets of the US, the UK and Japan. They find that investors can gain from portfolio diversification in the MENA region but not the Asian region. All the Islamic stock markets are integrated with the major stock markets. In addition, Abdul Majid and Kassim (2010) examine the degree of integration among five major Islamic stock markets, namely Malaysia, Indonesia, Japan, the US and the UK. The study finds that Islamic stock markets provide benefit of portfolio diversification across economic grouping but not within the same economic groupings. In recent findings, using the cross wavelet coherency, Dewandaru, Alaoui, Masih, and Alhabshi (2013) found that Gulf Cooperation Council (GCC) Islamic stock markets are found to be highly integrated with the ASEAN markets.

Unlike previous studies documented on the Islamic stock markets integration, there have been no studies exploring the factors that drive the Islamic stock markets integration. Therefore, investigation of the forces behind the Islamic stock markets integration shall provide a better understanding of the functioning of the global Islamic stock markets. In addition, investors and policy-makers are able to make prediction of macroeconomic changes on the stock markets integration and several scenarios can be analyzed. Thus, this study attempts to partially fill the gap in the literature and provide fresh empirical evidence on the driving forces behind the Islamic stock markets integration.

The rest of this paper is structured as follows. Section 2 provides the empirical framework and description of the data. Section 3 discusses empirical results and discussion. Lastly, Section 4 offers concluding remarks.

\section{Empirical Framework and Data}

Pretorius (2002) has classified three main factors that lead to the co-movement among different stock markets namely are contagion effect, economic integration and stock market characteristics. Contagion refers to the co-movement of stock markets that cannot be explained by economic fundamental. The economic integration refers to the more the economies of two countries are integrated, the more interdependent their stock markets. Lastly, the stock market characteristics are related to industrial similarity, volatility and market size. Unlike Pretorious (2002) and Karim and Ning (2012), the Islamic stock markets integration of two countries is measured using the dynamic correlation between daily rates of return of the two countries. Following Pretorius (2002) and Karim and Ning (2012), the estimated model is as follows:

$$
Y_{i t}=\alpha+\chi \text { Trade }_{i t}+\text { dInflation }_{i t}+\delta \text { Growth }_{i t}+\pi \text { Volatility }_{i t}+\varepsilon_{i t}
$$

where

$\mathbf{Y}=$ Dynamic correlation between daily rate of return of countries $p$ and $q$

Trade $=$ ratio of imports and exports from country $p$ to country $q$ with the total exports and imports of country $p$.

Inflation $=$ Inflation differentials between countries $p$ and $q$

Growth $=$ economic growth differentials between countries $p$ and $q$

Volatility $=$ Ratio of the variances of the returns in countries $p$ and $q$

The daily Islamic stock indices for Malaysia, Indonesia, Japan, China, Hong Kong, United Kingdom, India, Pakistan, Canada, Sri Lanka and United States data are obtained from both Datastream and Google Finance. Data of Inflation 
rates, interest rates and GDP were extracted from International Financial Statistics, International Monetary Fund (IMF). Trade data were obtained from the IMF's Direction of Trade publication. All data are spanning from 2010 to 2014.

Both pooled OLS and panel data estimation are employed in this study. All data are in a balanced panel. There are two broadly classes of panel estimator techniques which are fixed effect and random effect models. In order to get which specification is preferred, we use the Hausman test. From the previous studies, they suggest that trade coefficient shall carry positive sign while inflation differential, growth rates differential and volatility will be negatively correlated.

\section{Empirical Results}

\subsection{Descriptive Statistics}

Table 1 provides summary statistics of all the variables used in this study. It is interesting to note that the mean of dynamic correlation was low at 0.045 which indicates that to some extent the Islamic stock markets are less integrated. However based on the minimum and maximum value of correlation coefficients, some Islamic stock markets are strongly integrated (-0.4053 to 0.7732$)$. On average, the GDP growth differential is at $0.70 \%$ while the inflation differential is at $-0.11 \%$ that indicates some markets enjoy low inflation rate. In terms of trade, these markets contribute to $8 \%$ of a country bilateral trade.

Table 1. Summary Statistics

\begin{tabular}{llllll}
\hline Variables & DCORR & GROWTH & INFLATION & TRADE & VOLATILITY \\
\hline Mean & 0.0445 & 0.7037 & -0.1118 & 0.0807 & 1.4071 \\
Median & 0.0192 & 0.7760 & -0.0902 & 0.0406 & 1.2531 \\
Maximum & 0.7732 & 9.7633 & 12.7121 & 0.7216 & 5.3993 \\
Minimum & -0.4053 & -8.6592 & -14.6009 & 0.0044 & 0.2218 \\
Std. Dev. & 0.1533 & 3.7012 & 4.7994 & 0.1246 & 0.7984 \\
Skewness & 1.6086 & -0.0457 & -0.1343 & 3.7009 & 1.2158 \\
Kurtosis & 8.5646 & 2.3202 & 3.1350 & 17.4923 & 5.2643 \\
Jarque-Bera & $378.71^{* * *}$ & $5.39^{*}$ & 1.04 & $3034.32^{* * *}$ & $126.49^{* * *}$ \\
Probability & 0.0000 & 0.0675 & 0.5957 & 0.0000 & 0.0000
\end{tabular}

Notes: $* * *$ and $*$ indicate significant at $1 \%$ and $10 \%$ level respectively.

\subsection{Correlation Analysis}

Standard correlation coefficients among the variables of interest are reported in Table 2. From the table, the correlation coefficients are varied from -0.0098 to 0.4182 . Among the pairs, growth-inflation recorded the highest correlation at 0.4182 while stock markets correlation-inflation recorded the lowest at- 0.0098 . In addition, only trade shows the highest coefficient with the stock markets correlation at -0.1121 .

Table 2. Correlation Coefficients

\begin{tabular}{llllll}
\hline Variables & DCORR & GROWTH & INFLATION & TRADE & VOLATILITY \\
\hline DCORR & 1.0000 & & & & \\
GROWTH & 0.0344 & 1.0000 & & & \\
INFLATION & -0.0098 & 0.4182 & 1.0000 & & \\
TRADE & -0.1121 & 0.0389 & 0.0873 & 1.0000 & \\
VOLATILITY & -0.0641 & -0.1682 & 0.1788 & 0.0313 & 1.0000 \\
\hline
\end{tabular}

\subsection{Pooled OLS and Panel Data Results}

The results of both pooled OLS and panel data estimation are presented in Table 3. From the Hausman test result, it suggests that the fixed effect specification is preferred.

The results from the pooled OLS show that all variables are insignificant explaining the Islamic stock markets integration. From the panel estimation, the study revealed that only GDP growth differential and inflation differential 
are significant at $5 \%$ influencing the Islamic stock markets integration. In terms of growth differential, the results are consistent with Dorodnykh (2003), Bekaert et al. (2007) and Carrieri et al. (2007). For example, Bekaert et al. (2007) provide evidence that the positive economic growth of countries contributing to the economic integration across the countries. In addition, Carrieri et al. (2007) also found a positive relation of such variables in the stock market co-movement. However, the results are not consistent with those of Johnson and Soenen (2002) and Mobarek et al. (2014). Johnson and Soenen (2002) argued that the high growth differential rate in gross domestic products has negative impact on the Asian stock markets integration. Moreover, Mobarek et al. (2014) also found evidence that the economic growth negatively responds to the stock market integration.

Table 3. Regression Results

\begin{tabular}{lll}
\hline Variables & Pooled OLS & $\begin{array}{l}\text { Panel Data } \\
\text { (Fixed Effect) }\end{array}$ \\
\hline Growth & 0.0013 & $0.0090^{* *}$ \\
& $(0.62)$ & $(0.02)$ \\
Inflation & 0.0005 & $0.0065^{* *}$ \\
& $(0.79)$ & $(0.02)$ \\
Trade & -0.076 & -0.1213 \\
& $(0.30)$ & $(0.13)$ \\
Volatility & -0.0037 & -0.0243 \\
& $(0.75)$ & $(0.16)$ \\
C & $0.0576^{* * *}$ & $0.0856^{* * *}$ \\
& $(0.00)$ & $(0.00)$ \\
Hausman test & - & 18.26 \\
R2 & & $(0.00)$ \\
F-Test & 0.0100 & 0.2238 \\
\end{tabular}

Notes: $* * *$ and $* *$ indicate significant at $1 \%$ and $5 \%$ level respectively. Figure is brackets are p-values.

In terms of inflation differential, the results seem not consistent with Pretorius (2002) and Becker and Nautz (2012). Pretorius (2002) clarifies that when the inflation rates are converging, the stock markets shall be moving in parallel, while when the rates are diverging, the stock markets are moving in the opposite way. Hence, this suggests that the absolute value of inflation differential has shown a negative relationship on the stock market integration. Becker and Nautz (2012) also argued that a highly correlated market, the inflation rate computed by the price dispersion should be small. However, our results show that inflation differential has significant positive impact on the market integration. The higher dispersion of inflation rate the more integrated the Islamic stock markets. This also indicates that the Islamic stock markets can provide a shield against the inflation.

Our findings of trade seem not in line with the view that the stronger the bilateral trade ties among the countries, the higher the degree of integration of the stock markets (Masih and Masih, 1999; Pretorius, 2002; Kearney and Lucey, 2004; Karim and Majid, 2010; Karim and Hoe, 2012). However, Hooy and Goh (2007) found that reduction of trade barrier do increases the market co-movement but the trade intensity of the countries increases the market segmentation. Besides that, Liu, Lin and Lai (2006) also provide evidence that for European countries, the trade relation is largely and significantly explain the market interdependence, while for the Asian countries, the trade relation is zero and some negative and are insignificant in explaining the market interdependence.

Interestingly, although the coefficient is not significant, the result of negative relationship between Islamic stock markets integration and volatility are consistent with those of Pretorius (2002) and Karim and Hoe (2012). Pretorius (2002) notes that the two stock markets whose volatilities converge (diverge), the prices should also converge (diverge). For example, two markets with more or less the same volatility must yield more or less the identical returns. 


\section{Conclusion}

This study examines the determinants of Islamic stock markets integration among ten selected Islamic stock markets of Malaysia, Indonesia, Japan, China, Hong Kong, United Kingdom, India, Pakistan, Canada, Sri Lanka and United States. From the low mean of dynamic correlation, to some extent the Islamic stock markets are less integrated thus this shall provide potential benefits from international portfolio diversification in these markets. However based on the minimum and maximum value of correlation coefficients, some of Islamic stock markets are strongly integrated. The results from the pooled OLS show that all variables are insignificant explaining the Islamic stock markets integration. From the panel estimation, the study revealed that only GDP growth differential and inflation differential are significant influencing the Islamic stock markets integration. This indicates that the higher dispersion of GDP and inflation rate, the more integrated the Islamic stock markets. Bekaert et al. (2007) provide evidence that the positive economic growth of countries contributing to the economic integration across the countries. In addition, the inflation differential has significant positive impact on the market integration. The higher dispersion of inflation rate the more integrated the Islamic stock market indicating that the Islamic stock markets can provide a shield against the inflation.

The degree of integration among the Islamic stock markets has major implications on the devising of the financial policies of international corporations, policy makers and international investors (Karim and Hoe, 2012). In addition, the efficiency of the economy policies of each Islamic stock market dealing with its stock market disparity depends on the degree of financial integration of each stock market with the rest (Abdul Majid et al. 2008). Thus, investors may find limited opportunity from international diversification in some Islamic stock markets as the markets are more integrated. In addition, relying on certain macroeconomic variables, policy makers and investors will be able to make predictions of market integration.

This study has limitations as it only focuses on ten selected Islamic stock markets and selected macroeconomic variables, future research can include more countries with different regions such as MENA countries, conventional stock indices and other factors that lead for market integration. Some of probable factors that can be considered such as contagion effect, market capitalization, exchange rate, regional factor and interest rates. This shall enrich the findings in this subject matter in the future.

\section{Acknowledgement}

Financial support from the Ministry of Higher Education Malaysia through Research Acculturation Collaborative Effort (RACE) Grant Scheme [Grant No: RACE/1251/2015(07)] is gratefully acknowledged.

\section{References}

Abdul Majid, M.S. \& Kassim, S.H. (2009). Impact of the 2007 US financial crisis on the emerging equity markets. International Journal of Emerging Markets, 4(4), 341-357. https://doi.org/10.1108/17468800910991241

Abdul Majid, M.S., Meera, A.K.M., \& Omar, M.A. (2008). Interdependence of ASEAN-5 stock markets from the US and Japan. Global Economic Review, 37(2), 201-225. https://doi.org/10.1080/12265080802021201

Abd. Majid, M.S., Mohd. Yusof, R., \& Razali, A.N. (2007). Dynamic financial linkages among selected OIC Countries. Journal of Economic Cooperation, 28(2), 25-56.

Becker, S. S., \& Nautz, D. (2012). Inflation, price dispersion and market integration through the lens of a monetary search model. European Economic Review, 56(3), 624-634. https://doi.org/10.1016/j.euroecorev.2012.01.004

Bekaert, G., Harvey, C. R., Lundblad, C., \& Siegel, S. (2007). Global growth opportunities and market integration. The Journal of Finance, 62(3), 1081-1137. https://doi.org/10.1111/j.1540-6261.2007.01231.x

Bley, J. \& Chen, K.H. (2006). Gulf Cooperation Council (GCC) stock markets: the dawn of a new era. Global Finance Journal, 17, 75-91. https://doi.org/10.1016/j.gfj.2006.06.009

Carrieri, F., Errunza, V., \& Hogan, K. (2007). Characterizing world market integration through time. Journal of Financial and Quantitative Analysis, 42(4), 915-940. https://doi.org/10.1017/S0022109000003446

Chowdhury, M.B. (2005). Trade reforms and economic integration in South Asia: SAARC to SAPTA. Applied Econometrics and International Development, 5(4), 23-40.

Darrat, G. \& Wallace, M. (1992). On the integration of emerging stock markets in the Middle East. Journal of Economic Development, 25, 119-129.

Dewandaru, G., Alaoui, A., Masih, A. M. M., \& Alhabshi, S. O. (2013). Comovement and resiliency of Islamic equity market: Evidence from GCC Islamic equity index based on wavelet analysis (Working paper No. 56980). 
Retrieve from Munich Personal RePEc Archive website: https://mpra.ub.uni-muenchen.de/56980/

Dorodnykh, E. (2013). Stock market integration: An international perspective. Palgrave Macmillan.

Francis, I., Kim, S., \& Yoon, J.H. (2002). International stock market linkages: Evidence from the Asian financial crisis. Journal of Emerging Market Finance, 1, 1-29. https://doi.org/10.1177/097265270200100102

Grubel, H. (1968). International diversified portfolio: Welfare gains and capital flows. American Economic Review, $58,1299-1314$.

Hooy, C. W., \& Goh, K. L. (2007, March). The determinants of stock market integration: A Panel data investigation. In 15th Annual Conference on Pacific Basin Finance, Economics, Accounting, and Management Proceeding. 20\&21 July, Ho Chi Minh City, Vietnam.

Hussin, M.Y.M., Yusof, Y.A., Muhammad, F., Razak, A.A., Hashim, E., \& Marwan, N. F. (2013). The integration of Islamic stock markets: Does a problem for investors? Labuan e-journal of Mualamat and Society, 7, 17-27.

Johnson, R., \& Soenen, L. (2002). Asian economic integration and stock market comovement. Journal of Financial Research, 25(1), 141-157. https://doi.org/10.1111/1475-6803.00009

Karim, B. A., \& Hoe, X.N. (2013). Driving forces of the ASEAN-5 stock markets integration. Asia-Pacific Journal of Business Administration, 5(3), 186-191. https://doi.org/10.1108/APJBA-07-2012-0053

Kabir, S. H., Dewandaru, G., \& Masih, M. (2013). Are Islamic stock market integrated globally? Evidence from time series techniques. Australian Journal of Basic and Applied Sciences, 7(7), 702-720.

Karim, B.A. \& Majid, M.S.A. (2010). Does trade matter for stock market integration. Studies in Economics and Finance, 27(1), 47-66. https://doi.org/10.1108/10867371011022975

Kassim, S. H. (2013). The global financial crisis and the integration of Islamic stock markets in developed and developing countries. Asian Academy of Management Journal of Accounting and Finance, 9(2), 75-94.

Kearney, C., \& Lucey, B. M. (2004). International equity market integration: Theory, evidence and implications. International Review of Financial Analysis, 13, 571- 583. https://doi.org/10.1016/j.irfa.2004.02.013

Levy, H. \& Sarnat, M. (1970). International diversification of investment portfolios. American Economic Review, 60, 668-675.

Liu, S. Z., Lin, K. C., \& Lai, S. M. (2006). Stock market interdependence and trade relations: A correlation test for the US and its trading partners. Economics Bulletin, 7(5), 1-15.

Marashdeh, H. (2005). Stock market integration in the MENA region: An application of the ARDL bounds testing approach (Working paper No. 05-27). Retrieve from Department of Economics, University of Wollongong website

Masih, A. M. M., \& Masih, R. (1999). Are Asian stock market fluctuations due mainly to intra-regional contagion effects? Evidence based on Asian emerging stock markets. Pacific- Basin Finance Journal, 7, 251-82. https://doi.org/10.1016/S0927-538X(99)00013-X

Mobarek, A., Muradoglu, G., \& Mollah, S. (2014). Determinants of time varying co movements among international stock markets. Retrieve from http://www.efmaefm.org/0EFMAMEETINGS/EFMA\%20ANNUAL\%20MEETINGS/2014-Rome/papers/EF MA2014_0550_fullpaper.pdf

Pretorius, E. (2002). Economic determinants of emerging stock market interdependence. Emerging Markets Review, 3(1), 84-105. https://doi.org/10.1016/S1566-0141(01)00032-2 